\title{
Synthesis of water resistant and biostable polyvinyl acetate dispersions
}

\author{
(C) Aygul G. Suleymanova, ${ }^{1+}$ Erik R. Khusainov, ${ }^{1}$ \\ Regina R. Spiridonova, ${ }^{2} *$ and Alexander S. Sirotkin ${ }^{2}$ \\ ${ }^{1}$ Department of Technology of Synthetic Rubber. ${ }^{2}$ Department of Industrial Biotechnology. \\ Kazan National Research Technological University. Karla Marksa St., 68. Kazan, 420015. \\ Republic of Tatarstan. Russia. Phone: ${ }^{1)}$ (843) 231-42-14, ${ }^{2)}$ (843) 231-89-19. \\ E-mail: sulejmanova.1992@list.ru, asirotkin66@gmail.com
}

\begin{abstract}
*Supervising author; ${ }^{+}$Corresponding author
Key words: vinyl acetate emulsion polymerization, silica, titanium dioxide, polyhexamethylene guanidine hydrochloride, water resistance, fongicidal.
\end{abstract}

\begin{abstract}
The characteristics of the emulsion polymerization of vinyl acetate in the presence of inorganic compounds such as silicon dioxide, titanium dioxide and polyhexamethylene guanidine hydrochloride are studied. It was found that, under the same synthesis conditions, inorganic additives affect the polymerization mechanism of vinyl acetate. The highest conversion of vinyl acetate can be obtained with the introduction of $0.5 \mathrm{wt} \%$ silicon dioxide. Polyhexamethylene guanidine hydrochloride also accelerates the reaction rate at the initial moment of time. However, the combined use of silicon dioxide and polyhexamethylene guanidine hydrochloride also reduces the reaction rate in comparison with the syntheses of vinyl acetate, carried out in the presence of each additive separately. The introduction of titanium dioxide, on the contrary, inhibits the reaction. However, when titanium dioxide and polhexamethylene guanidine hydrochloride are used together, the curve of the dependence of vinyl acetate conversion on time is close in process speed to the polymerization process of vinyl acetate without additives. The introduction of silicon dioxide and titanium dioxide makes it possible to increase by 1.5 times the water resistance of the resulting dispersions after shortterm keeping glued samples in the water. At the same time, an increase in the water resistance of the samples after long-term contact with water allows only silica. The joint introduction of polyhexamethylene guanidine hydrochloride and silicon dioxide also led to improve the water resistant of adhesive joints, but not as significantly as in the case of the separate introduction of only silica. Polyhexamethylene guanidine hydrochloride increases the fungicidal activity of the resulting dispersions, and its combined use with titanium dioxide made it possible to improve the water resistance of the dispersion during long-term contact with water, in contrast to samples modified only with titanium dioxide. In addition, these samples showed greater fungicidal activity than samples containing silica and polymethylene guanidine hydrochloride.
\end{abstract}

\section{References}

[1] V.N. Volynsky. Technology of glued materials. Textbook for universities, Arkhangelsk, publishing house of Arkhang. state techn.un-ty. 2003. 280p. (russian)

[2] J. Sleist. Handbook of adhesives. N.Y., Van Nostrand Reinhold Publ. 1977. 922p.

[3] I.G. Kanevskaya. Biological damage to industrial materials. Leningrad: Science. 1984. 232p. (russian)

[4] S.S. Gayduk. Study of the strength and water resistance of adhesive joints based on PVA-dispersions. Proceedings BSTU. Forestry and woodworking industry. 2012. No.2. P.172-174. (russian)

[5] T. Bardak, A.N. Tankut, N. Tankut, E. Sozen, D. Aydemir. The effect of nano- $\mathrm{TiO}_{2}$ and $\mathrm{SiO}_{2}$ on bonding strength and structural properties of poly (vinyl acetate) composites. Measurement: Journal of the International Measurement Confederation. 2016. Vol.93. P.80-85.

[6] A. Ślusarczyk, H. Kuczyńska, M. Piotrowska. Examinations of antimicrobial properties of Cu, nano $\mathrm{ZnO}$ and Ag in coatings. Conference materials, XXIX FATIPEC Congress. 2008. Ghent. 99p.

[7] O.E. Babkin, L.I. Aristova. Wood protection from biodegradation. Paints and varnishes. 1996. No.12. P.21-23. (russian)

[8] Leon P. O'Malley, Andrew N. Collins, Graham F. White. Biodegradability of end- group of the biocide polyhexamethylene biguanide (PHMB) assessed using model compounds. Journal of Industrial Microbiology \& Biotechnology. 2006. Vol.33. P.677-684. 
[9] L.F. Minnebaeva, T.V. Vdovina, et al. Evaluation of the biostability of aqueous dispersions of polyvinyl acetate and materials based on them. Bulletin of the Technological University. 2017. No.11. Vol.20. P.134-136. (russian)

[10] A.P. Grigoriev. Laboratory Workshop on Plastics Technology: a training manual for chemical technology. in 2 parts. Part 1. Moscow: Vysshaya Shkola. 1977. 249p. (russian)

[11] Chen, X., \& Mao, S. S. (2007, July). Titanium dioxide nanomaterials: Synthesis, properties, modifications and applications. Chemical Reviews.

[12] A.M. Shur. Vysokomolekulyarnye soedineniya (High-Molecular-Mass Compounds), Moscow: Vysshaya Shkola. 1981. 656p. (russian)

[13] S.Yu. Doronin, R.K. Chernova, V.V. Alipov, M.S. Lebedev, O.G. Shapoval. Synthesis and bactericidal properties of ultrafine copper powder (abstract). Butlerov Communications. 2011. Vol.25. No.8. P.122123. ROI: jbc-02/11-25-8-122

[14] D.V. Sugonyako, L.A. Zenitova. Polymer compounds and nanocompounds based on silica. Butlerov Communications. 2015. Vol.43. No.9. P.78-83. DOI: 10.37952/ROI-jbc-01/15-43-9-78

[15] G.F. Garayeva, A.I. Rodionova, D.O. Gnezdilov, R.R. Spiridonova, Y.D. Samuilov, F.B. Balabanova. Influence akrol-C on the synthesis and properties of polyvinyl in individual solvents. Butlerov Communications. 2012. Vol.31. No.8. P.66-72. ROI: jbc-02/12-31-8-66 